\title{
20. A SEISMIC REFLECTION STUDY OF THE RIO GRANDE RISE1
}

\author{
Peter F. Barker, Department of Geological Sciences, Birmingham University, Birmingham B15 2TT, England \\ Richard T. Buffler, ${ }^{2}$ Galveston Marine Geophysics Laboratory, University of Texas at Austin, Galveston, Texas \\ and \\ Luiz A. Gamboa, ${ }^{3}$ Lamont-Doherty Geological Observatory, Palisades, New York
}

\begin{abstract}
Seismic reflection profiles have been interpreted in combination with deep-sea drilling data to examine the sedimentary evolution of the Rio Grande Rise.

Restricted and unevenly distributed seismic reflection coverage (particularly multichannel) and limited well control confined most of our interest to the northern flank of the main western elevated block of the Rise, near to DSDP Site 516. The basement of much of the Rise above approximately $3000 \mathrm{~m}$ present depth has the "dipping reflector" character of some continental margins, produced by interbedded lavas and sediments formed directly above sea level. The overlying Late Cretaceous and early Tertiary sediments are mainly pelagic, but lap onto originally subaerial basement in places. A major middle Eocene tectonic event (involving uplift, tilting, faulting, and probably local volcanism) resulted in subaerial erosion, submarine slumping, and turbidite deposition. Submarine slides associated with the early stages of this tectonism probably caused the chaotic midsection reflector sequence identified with the middle Eocene Unit 4 at Site 516. Middle Eocene tectonism also produced the central graben of the Rise, which contains rotated fault blocks, and the broad guyot between the graben and Site 516. The guyot shows thick sequences dipping away from the graben and truncated, presumably by subaerial erosion. Prograded biogenic debris, swept off the top by bottom currents after resubmergence in the Oligocene, extended the guyot's top farther. Biogenic debris from the same source probably formed the initial load of the density currents that have dissected the steeper northern slopes of the Rise. Interpretation of reflection profiles from all around the Rise suggests erosion between depths of 2000 and $3600 \mathrm{~m}$, even where the creation of density currents upslope is unlikely; a component of contour current erosion by North Atlantic Deep Water may be involved. The Vema Terrace, which in the west separates the Rio Grande Rise from the Vema Channel, shows signs of sedimentation from turbidity currents originating on the Rise. The Terrace and the Vema Channel extend around the north flank of the Rise also; their positions are controlled by the topography of the east-west Rio Grande Fracture Zone. If the eastward flow of Antarctic Bottom Water north of the Rise is inferred, the direct transport of debris from the Rise to the Brazil Basin by turbidity currents becomes a more complex process.
\end{abstract}

\section{INTRODUCTION}

The Rio Grande Rise, an abnormally elevated region of the western South Atlantic, is currently of great tectonic and paleoceanographic interest. The origin of the Rise, at the ridge crest or by off-axis hot-spot activity, and its relationship to the congruent Walvis Ridge have been vigorously debated (see Barker and Carlson, this volume, for a summary). Since its formation, the Rise has been both a prominent topographic influence on ocean circulation and a repository of the sedimentary record of that circulation, over a great range of water depths and away from the less stable depositional environment of the continental margin.

Because of these two interacting concerns (the origin of the Rise and its influence on deep-sea circulation), one of the main objectives of DSDP Leg 72 at Site 516 was to core continuously to basement on the northern shoulder of the Rise. The resulting insights into the history of the Rise (Barker et al., 1981) would alone justify

${ }^{1}$ Barker, P. F., Carlson, R. L., Johnson, D. A., et al., Init. Repts. DSDP, 72: Washington (U.S. Govt. Printing Office).

78751 .

2 Present address: Dept. of Geophysics, The University of Texas, Austin, Austin, Texas 10965. reexamination of the regional seismic reflection coverage, which was last studied after Leg 39 drilling (McDowell et al., 1977) and subsequent piston coring (Johnson and Peters, 1979). In addition, the preliminary site survey for Leg 72 included the first multichannel seismic reflection profiles across the Rise, which are noticeably superior to existing single-channel data in both penetration and time-stratigraphic resolution.

Because of the uneven coverage and poor quality of some of the data, we have not attempted a regional analysis of sediment distribution. Rather, we have used the new multichannel profiles in the area around Site 516 to extend the insights provided by drilling; extrapolation to the remainder of the Rio Grande Rise is secondary and necessarily more speculative. We use the terminology and concepts of seismic stratigraphy (e.g., Mitchum et al., 1977), but have not attempted a full stratigraphic analysis because of the limited amount of multichannel data and the speculative nature of many correlations.

The Rio Grande Rise separates the Brazil Basin from the Argentine Basin and is bounded approximately by $33^{\circ}$ and $28^{\circ} \mathrm{S}, 38^{\circ}$ and $28^{\circ} \mathrm{W}$ (Fig. 1). To the east between $28^{\circ}$ and $25^{\circ} \mathrm{W}$ lies the deep water of the Hunter Channel and to the west the narrow Vema Channel, beyond which other, much more subdued basement highs 


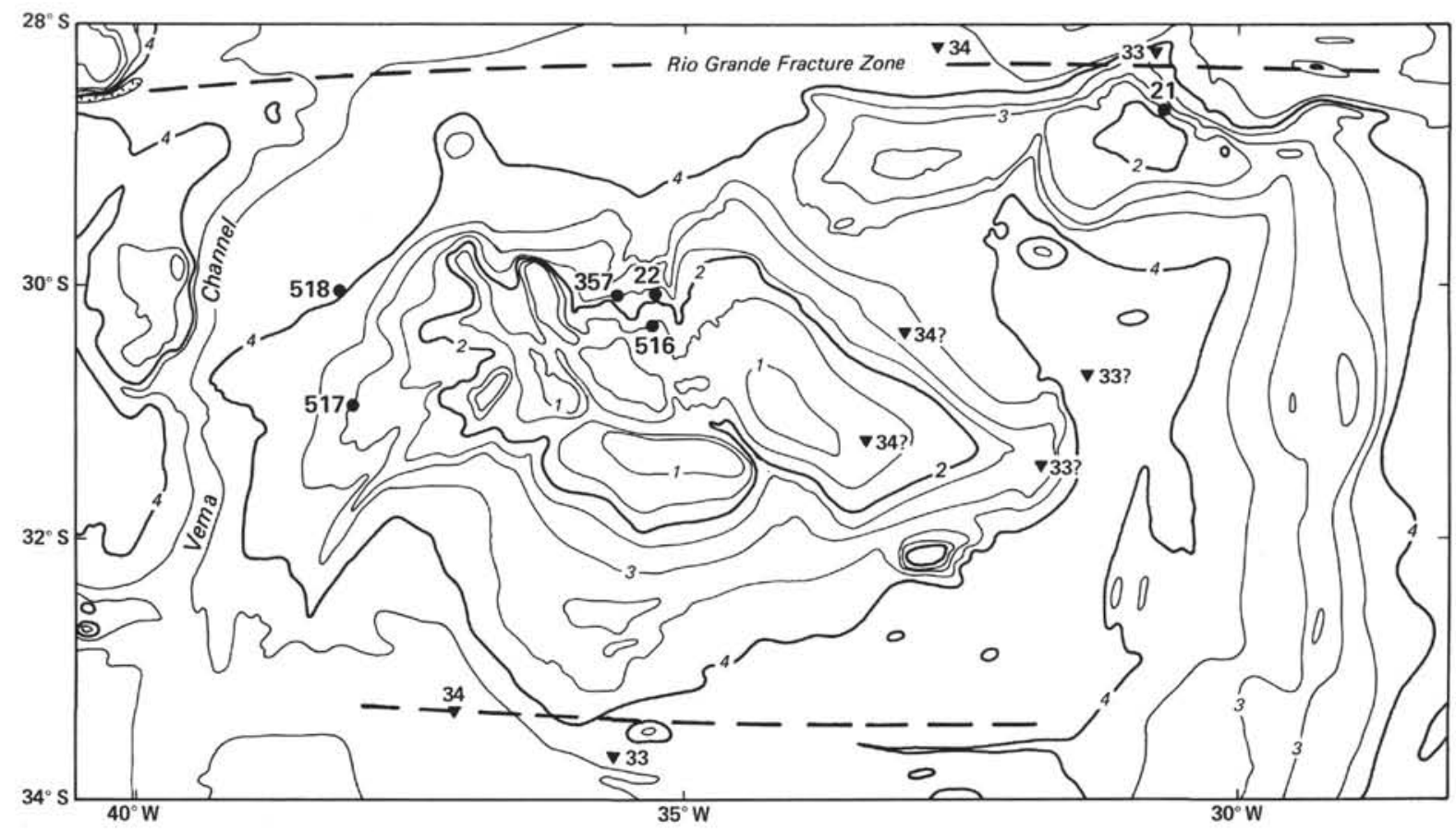

Figure 1. Rio Grande Rise bathymetry and location of DSDP sites. Contour interval is $0.5 \mathrm{~km}$; guyots are defined by $1-\mathrm{km}$ isobath. (Compiled from Lonardi and Ewing, 1971, and Moody and others, 1979)

extend to the South American margin. The Rio Grande Rise has an eastern and a western part, which are morphologically distinct. They are separated in the south by a basin of normal oceanic depth, but in the north are joined by an east-west ridge lying directly south of the Rio Grande Fracture Zone, which extends along $28.5^{\circ} \mathrm{S}$ (Gamboa and Rabinowitz, 1981). A second fracture zone is believed to define the southern boundary of the Rise along $33.5^{\circ} \mathrm{W}$ (Kumar, 1979; Cande and Rabinowitz, 1979).

The eastern component of the Rise is a north-south ridge, more pronounced in the north and smooth except for a small north-south graben at its northern end. The western component is larger and oval, with a long eastwest axis. Its slopes are not uniform (they have benches at varying heights on different flanks), but its most prominent feature is the set of eight guyots that form its crest. These have high points (depths to top) ranging between 560 and $900 \mathrm{~m}$, and are defined in Figure 1 by the 1000 -m contours. They lie approximately in a double line oriented along $120^{\circ}$, separated by a continuous trough (as far as can be seen-bathymetric data are sparse in places), and they tend to have steeper inner (toward the trough) slopes than outer. One other guyot with a similarly shallow high point (least depth to top) occurs near $32^{\circ} \mathrm{S} 33^{\circ} \mathrm{W}$, but it is separated from the main part of the Rise at the $3000 \mathrm{~m}$ level.

In view of the contrasting morphology of the eastern and western components of the Rio Grande Rise, we cannot assume a common tectonic evolution for the two components. Because the data distribution leads us to consider almost solely the western component, our use of the term "Rio Grande Rise" or merely "Rise" throughout the remainder of this paper will refer only to this western component.

\section{DATA DISTRIBUTION}

Figure 1 shows the locations of all DSDP sites drilled in the area. They are not all of equal value. At Sites 517 and 518 (site chapters, Sites 517 and 518, this volume), the maximum penetration was only to 51 and $77 \mathrm{~m}$ respectively, still within the wavetrain of the bottom reflection of a typical airgun seismic reflection profile. Penetration at Sites 21 and 22 (Maxwell, Von Herzen, et al., 1970) was greater (to 131 and $242 \mathrm{~m}$ respectively), but these sites were only spot-cored. Drilling at Site 357 penetrated to $797 \mathrm{~m}$, and coring (though still not continuous) was much more dense (Supko, Perch-Nielsen, et al., 1977). The value of Site 357 for regional seismic correlation is reduced, however, by its location within a zone where the upper 400 to $500 \mathrm{~m}$ of the sediment column is dissected by a network of submarine canyons. Thus, the $1271 \mathrm{~m}$ penetration and continuous coring at Site 516 make it the most useful site for interpretation of the reflection profiles (site chapter, Site 516, this volume). The proximity and similar sedimentary sections of Sites 357 and 22 provide secondary evidence of the generality of Site 516 results, within the northern shoulder province of the Rise.

The majority of available seismic reflection data in the Rio Grande Rise area are Lamont-Doherty (LDGO) single-channel profiles. Figure 2 includes only those obtained using an airgun source (i.e., Vema Cruise 22, Robert D. Conrad Cruise 11 onwards), because the older records lack adequate time-stratigraphic resolution. The tracks are unevenly distributed, but include detailed surveys around DSDP Site 21 and, more significantly, in the northern shoulder province that contains DSDP Sites 22, 357, and 516. Figure 3 contains an expanded track chart of the northern shoulder province. 


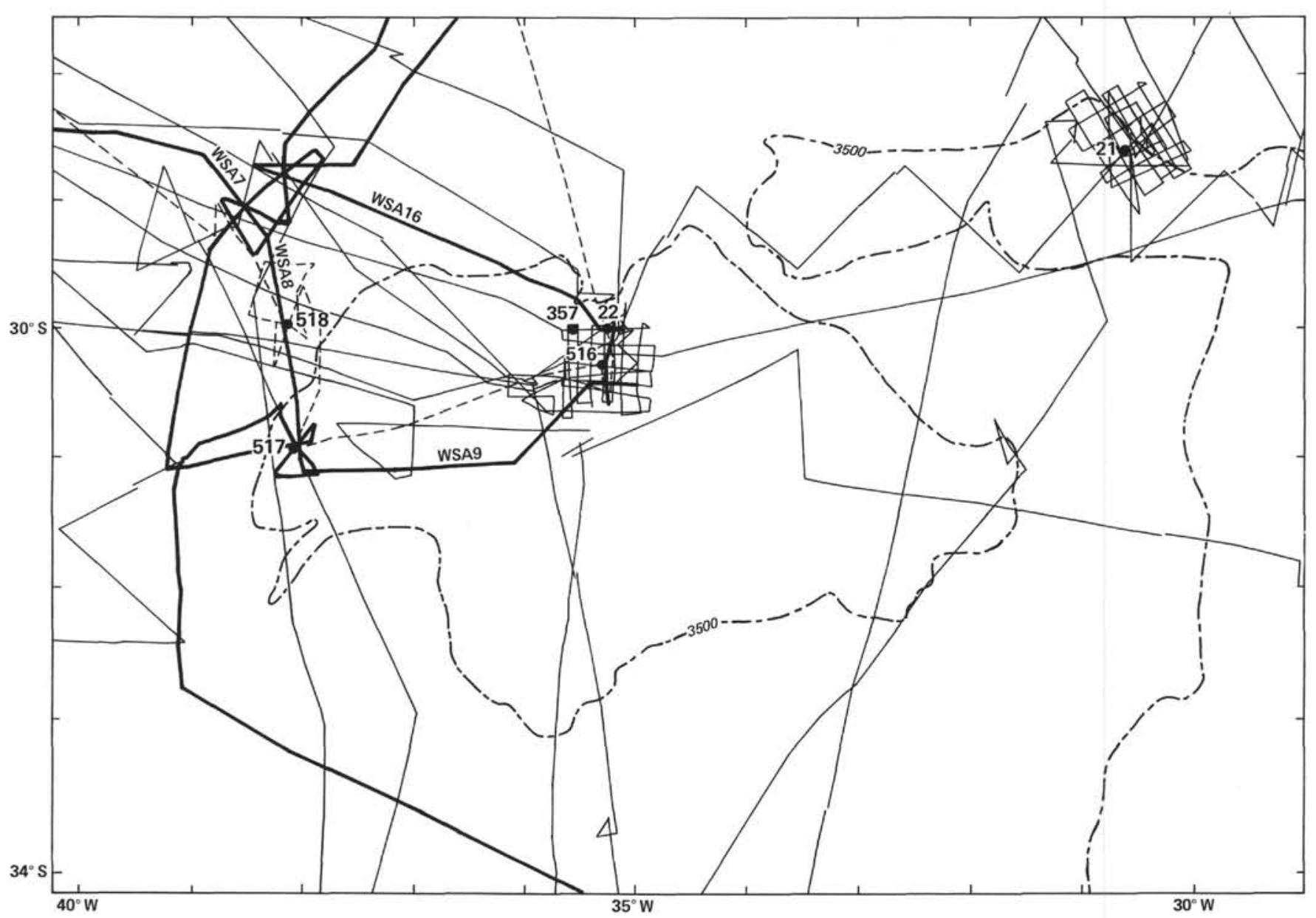

Figure 2. Tracks of seismic reflection profiles in Rio Grande Rise region, in relation to DSDP sites. Dashed lines are Glomar Challenger Leg 72 tracks. Thick solid lines are Fred H. Moore tracks, along which multichannel seismic reflection profiles were acquired (all others single channel); $3500-\mathrm{m}$ isobath defines Rio Grande Rise.

Glomar Challenger profiles from Legs 36, 39, 71, and 72 comprise the remaining single-channel airgun data. Those from Legs 36 (Barker, Dalziel, et al., 1976) and 71 (Ludwig, Krashenninikov, et al., in press) cross only the lower slopes of the Rise; those from Leg 39 (Neprochnov et al., 1977) are of uneven quality, because they were shot partly in bad weather. Leg 72 tracks are distinguished in Figures 2 and 3 by dashed lines. Although these tracks do not greatly improve the regional coverage, they pass directly over Site 516 and link it precisely to the remainder of the seismic reflection data set.

The multichannel seismic reflection profiles, obtained by the University of Texas Marine Science Institute (UTMSI) aboard Fred H. Moore during the site survey for the South Atlantic Legs 71 to 75 , lie along the thicker lines in Figures 2 and 3. A 24-channel streamer, with $50-\mathrm{m}$ group interval and a nominal $50-\mathrm{m}$ shot interval, gave 12 -fold common depth point (CDP) cover. The seismic source was either Maxipulse (10 ounce) or a lowpressure airgun array. In this analysis, we are concerned with Profiles WSA7, 8-11, 13, 15, and 16, which form a loop extending from the Vema Channel up the western flank of the Rise, across the crest, onto the northern shoulder past Site 516, then northwestward back to the Vema Channel. Line WSA13 runs within $3 \mathrm{~km}$ of Site
516 and is linked most precisely to the site by a short loop steamed by Glomar Challenger after the completion of drilling (Fig. 3).

\section{Site 516 Results}

The sedimentary section at Site 516 is fully described in the site chapter, Site 516, this volume; Table 1 summarizes the lithology. Basaltic basement, formed about $84 \mathrm{Ma}$ ago near sea level at an abnormally elevated section of the Mid-Atlantic Ridge, is overlain by a largely pelagic carbonate succession $1251 \mathrm{~m}$ thick. Apart from a 5-Ma hiatus in the late Miocene, sedimentation was continuous, and steady pelagic deposition was augmented only during the middle Eocene by thin, now-altered volcanic ash beds, partly volcaniclastic slumps and turbidites (Unit 4 of Table 1). Compaction and diagenesis of this calcareous biogenic ooze accounts for a general rise of compressional (p-wave) velocity with depth (Fig. 4). Superimposed upon this rise is a set of higher velocities within the partly volcanogenic Unit 4 . The high velocity values, however, are associated not with the volcaniclastic turbidites or slumps, but with the nearby limestones, and it is suggested that they are caused by fluid migration (primarily of silica) into the limestones from the volcaniclastic elements. 


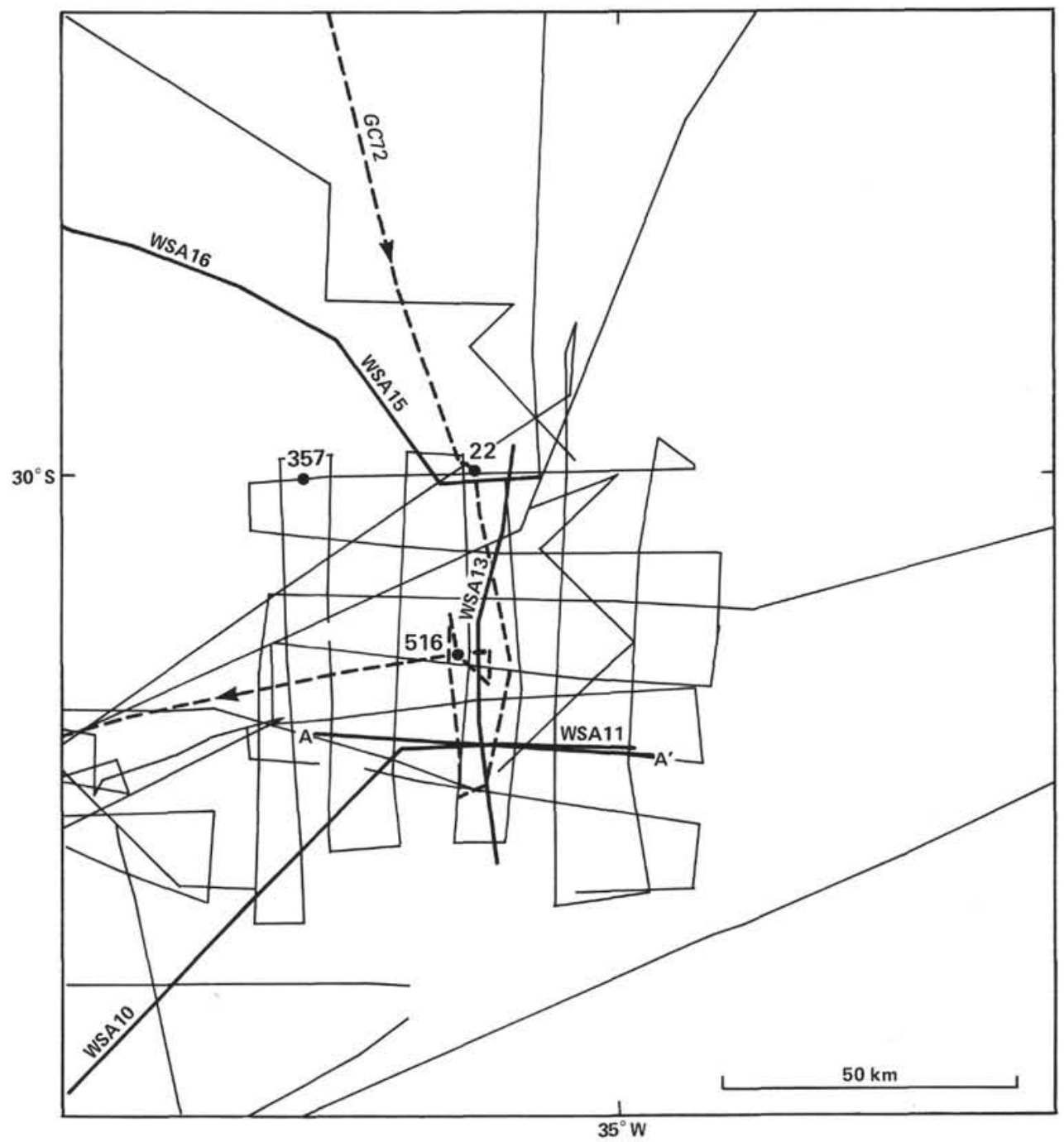

Figure 3. Tracks of seismic reflection profiles in northern shoulder area of Rio Grande Rise, close to Site 516. Thick lines are of multichannel profiles acquired aboard Fred $H$. Moore (UTMSI) and dashed lines Glomar Challenger Leg 72. AA' line locates Vema 26-06 single-channel profile Record 819 (Fig. 11).

The velocities plotted as solid circles in Figure 4 are shipboard, ambient-pressure measurements of horizontal (i.e., cross-core) p-wave velocities. The less numerous vertical (along-core) velocities measured under similar conditions were, on the average, about $5 \%$ lower (see Shaftenaar et al., this volume). However, previous laboratory studies on similar sediments (e.g., Carlson and Christensen, 1977) had shown that an increase of a similar magnitude occurred in horizontal and vertical velocities when samples were restored to in situ pressures. We concluded therefore that shipboard measurements of horizontal compressional-wave velocities remained reasonable approximations to in situ vertical velocities, and we used a velocity model fitted to these data to produce a time-depth curve (both shown as solid lines in Figure 4) to compare the drilled section with the reflection profiles.

More recent measurements at elevated pressures on samples from Hole 516F itself (Carlson et al., this vol- ume) now show that the effect is not so simple. The confining pressure used for these measurements $(0.1 \mathrm{kbar})$ can be equated to the overburden (nonhydrostatic) pressure at a depth of about $1 \mathrm{~km}$, assuming that the sediments themselves are not overpressured in situ. These laboratory-measured values of vertical velocity are shown as open circles in Figure 4, connected by a thin line to the shipboard measurement of horizontal velocity on the same sample. Overall, the differences between laboratory-measured and shipboard-measured velocities are quite variable. At shallower depths, there is a slight tendency toward higher laboratory-measured values, but because the experimental confining pressure exceeded the in situ overburden pressures for these sediments, no adjustment to the velocity model needed to be made. The only major systematic offset occurs in Unit 5, between 874 and $1000 \mathrm{~m}$, where shipboard values are, on the average, $0.33 \mathrm{~km} / \mathrm{s}$ lower. If the high-pressure laboratory experiment does approximately simulate in situ condi- 
Table 1. Lithology of Hole 516F sediments.

\begin{tabular}{|c|c|c|c|}
\hline Unit & $\begin{array}{l}\text { Interval } \\
(\mathrm{m})\end{array}$ & Age & Description \\
\hline 1 & $0-193$ & $\begin{array}{l}\text { Holocene to early } \\
\text { Miocene }\end{array}$ & $\begin{array}{l}\text { Foraminiferal and nannofossil ooze, pale brown to white; foraminiferal sand } \\
\text { layers occur near } 65 \mathrm{~m} \text {. }\end{array}$ \\
\hline 2 & $193-332$ & $\begin{array}{l}\text { early Miocene to late } \\
\text { Oligocene }\end{array}$ & $\begin{array}{l}\text { Light gray nannofossil ooze and chalk with chert nodules and biogenic silica; unit } \\
\text { boundaries defined by shallowest and deepest occurrences of chert. }\end{array}$ \\
\hline 3 & $332-634$ & $\begin{array}{l}\text { late Oligocene to middle } \\
\text { Eocene }\end{array}$ & $\begin{array}{l}\text { Light gray to greenish gray chalk and limestone; parallel laminations common } \\
\text { below } 470 \mathrm{~m} \text {; extensive burrowing throughout. }\end{array}$ \\
\hline 4 & $634-874$ & middle Eocene & $\begin{array}{l}\text { Interbedded pelagic limestone, volcanic ash layers, and allochthonous turbidites and } \\
\text { breccias; limestones are generally similar to Unit } 3 \text {, although } \mathrm{CaCO}_{3} \text { decreases } \\
\text { down section toward marly limestone }\left(<60 \% \mathrm{CaCO}_{3}\right) \text {. Ash layers are com- } \\
\text { monly altered to bentonite. Displaced units are variable in composition and } \\
\text { structure, including carbonate and volcanogenic components, graded sequences } \\
\text { and upgraded breccias, and some with mud clasts. Unit boundaries are (1) up- } \\
\text { permost turbidite layer and (2) the base of Maestrichtian limestone slumped } \\
\text { block. Amorphous silica cement is present below } 800 \mathrm{~m} \text {. Physical properties } \\
\text { show a transition to high density and velocity down section within the lime- } \\
\text { stone units of Unit } 4 \text { and a sharp decrease in both at the base. }\end{array}$ \\
\hline 5 & $874-1000$ & $\begin{array}{l}\text { middle Eocene to late } \\
\text { Maestrichtian }\end{array}$ & Nannofossil limestones, grading from light gray at the top of the unit to reddish \\
\hline Sa & $874-930$ & & $\begin{array}{l}\text { brown below } 930 \mathrm{~m} \text {. Anastomosing laminations (microstyolites) are common } \\
\text { throughout. This unit contains the Cretaceous/Tertiary boundary in Core } 89 \text {, }\end{array}$ \\
\hline $5 b$ & $930-1000$ & & $\begin{array}{l}\text { within which lithologic variability is striking (clay, marl, and limestone units } \\
\text { interbedded). The uppermost } 40 \text { m of Unit } 5 \text { contains amorphous silica, ap- } \\
\text { parently remobilized from the volcanics of Unit } 4 \text {. Kaolinite and illite are pres- } \\
\text { ent in Subunit } 5 \text { b, but not above. }\end{array}$ \\
\hline 6 & $1000-1240$ & $\begin{array}{l}\text { late Maestrichtian to } \\
\text { Coniacian-Santonian }\end{array}$ & $\begin{array}{l}\text { Greenish gray and reddish brown limestones and interbedded marly limestones in } \\
\text { Subunit 6a; greenish gray to dark gray recrystallized dolomitic limestones in }\end{array}$ \\
\hline $6 a$ & $1000-1130$ & & Subunit $6 \mathrm{~b}$. Bioturbation within both reddish and greenish intervals argues \\
\hline $6 \mathrm{~b}$ & $1130-1240$ & & $\begin{array}{l}\text { against anoxic conditions of deposition of Unit } 6 . \text { Inoceramus fragments are } \\
\text { abundant below } 1150 \mathrm{~m} \text {, with scattered occurrence as shallow as } 1080 \mathrm{~m} \text {. }\end{array}$ \\
\hline 7 & $1240-1251$ & Coniacian-Santonian & $\begin{array}{l}\text { Varicolored volcanic and calcareous turbidites and breccias. The uppermost sedi- } \\
\text { ment recovered in Core } 124 \text { consists of four cobbles of ferruginous chert, under- } \\
\text { lain by a } 20 \text {-cm-thick reddish limestone (probably pelagic) containing In- } \\
\text { oceramus fragments. The remaining sediments of Cores } 124 \text { and } 125 \text { are dis- } \\
\text { placed from shallower sites. }\end{array}$ \\
\hline 8 & $1251-1271$ & & $\begin{array}{l}\text { Olivine-plagioclase phyric tholeitic basalt; calcitic vein filling contains fragments of } \\
\text { coralline algae and bryozoa. }\end{array}$ \\
\hline
\end{tabular}

tions, and Unit 5 is not overpressured in situ, then the consequent change in the velocity model produces a change of about $1 \%$ in the time to the deeper reflectors.

\section{Connection to Profile WSA13}

Figure 5 connects the time-depth model at Site 516 to the reflectors on the multichannel profile WSA 13 by means of the short section of the single-channel Glomar Challenger profile. Because sediment densities and acoustic velocities vary together (fig. 10 of Barker et al., 1981, and site chapter, Site 516, this volume), reflectors should coincide with the prominent velocity changes modelled in Figure 4. Much of the Glomar Challenger profile, however, is difficult to interpret, because it is rich in reflections whose primary nature cannot be reliably established. A few stand out: a prominent reflector at 0.22 seconds (Fig. 5) may correlate with the velocity change near the base of Unit 1 at $180 \mathrm{~m}$, and a complex reflector at about $0.74 \mathrm{~s}$ is probably close to the uppermost "ash bed" at $665 \mathrm{~m}$ ( $0.74 \mathrm{~s}$ on the model) within Unit 4. A strong reflector at $1.04 \mathrm{~s}$ at Site 516 on the Glomar Challenger profile correlates with the abrupt velocity change at $1125 \mathrm{~m}(1.07 \mathrm{~s})$ at the top of Subunit $6 \mathrm{~b}$, the highest occurrence of recrystallized dolomitic limestones, rather than with the underlying basalt. Away from the site, the acoustic basement lies deeper, and at the intersection with WSA13, where the acoustic basement is at 1.10 to $1.14 \mathrm{~s}$, it correlates with basaltic basement (1.14 s, $1251 \mathrm{~m}$ sub-bottom at Site 516). With this last possible exception, all the reflectors on the Glomar Challenger profile at the site, whether primary or not, appear to carry across to Profile WSA13 with very little change in sub-bottom time. Thus we may correlate other reflectors on the much cleaner, deconvolved Profile WSA13 with the drilled section. In particular, the abrupt velocity inversion near the base of the middle Eocene Unit 4 (at $882 \mathrm{~m} 0.89 \mathrm{~s}$ on the model) correlates well with a reflector at $0.87 \mathrm{~s}$ on WSA13.

\section{Interval Velocities}

Interval velocities computed from the multichannel reflection profiles may have some diagnostic value away from the drill sites, but have to be used with care. Figure 6 shows RMS interval velocities calculated from velocity analyses of the CDP-stacked UTMSI Profiles WSA10, 11, and 13. Figure 7 compares the velocity section obtained from shipboard measurements on Site 516 cores (Fig. 4) with nearby interval velocities (chosen two-thirds from Profile WSA13 close to Site 516 and one-third from Profile WSA11 where it intersects WSA13). Clearly, the interval velocities in Figure 7 are higher than the measured velocities, and the velocity inversion below the middle Eocene Unit 4 is undetected. As outlined above, the velocity model of Figure 4 includes some assessment of the effects of measurement at ambient rather than in situ pressures and provides (Fig. 5) a reasonable fit (closer than 3\%) of core lithology to the time section. The CDP-derived interval velocities give depth estimates to the deeper layers near Site 516, which are about $20 \%$ greater than those in Figure 5. We do not know if velocity heterogeneity (particularly gradients), an abundance of diffracted energy and dips in the section, and undetected ship speed variations could, in combination, bias the interval velocities to this extent (see Al-Chalabi, 1979), but we prefer the sample-derived model and use the interval velocities only qualitatively.

\section{INTERPRETATION OF REFLECTION PROFILES}

The UTMSI multichannel Profiles WSA7, 8-11, 13, 15 and 16, shown in Figure 8 (back-pocket) and located 


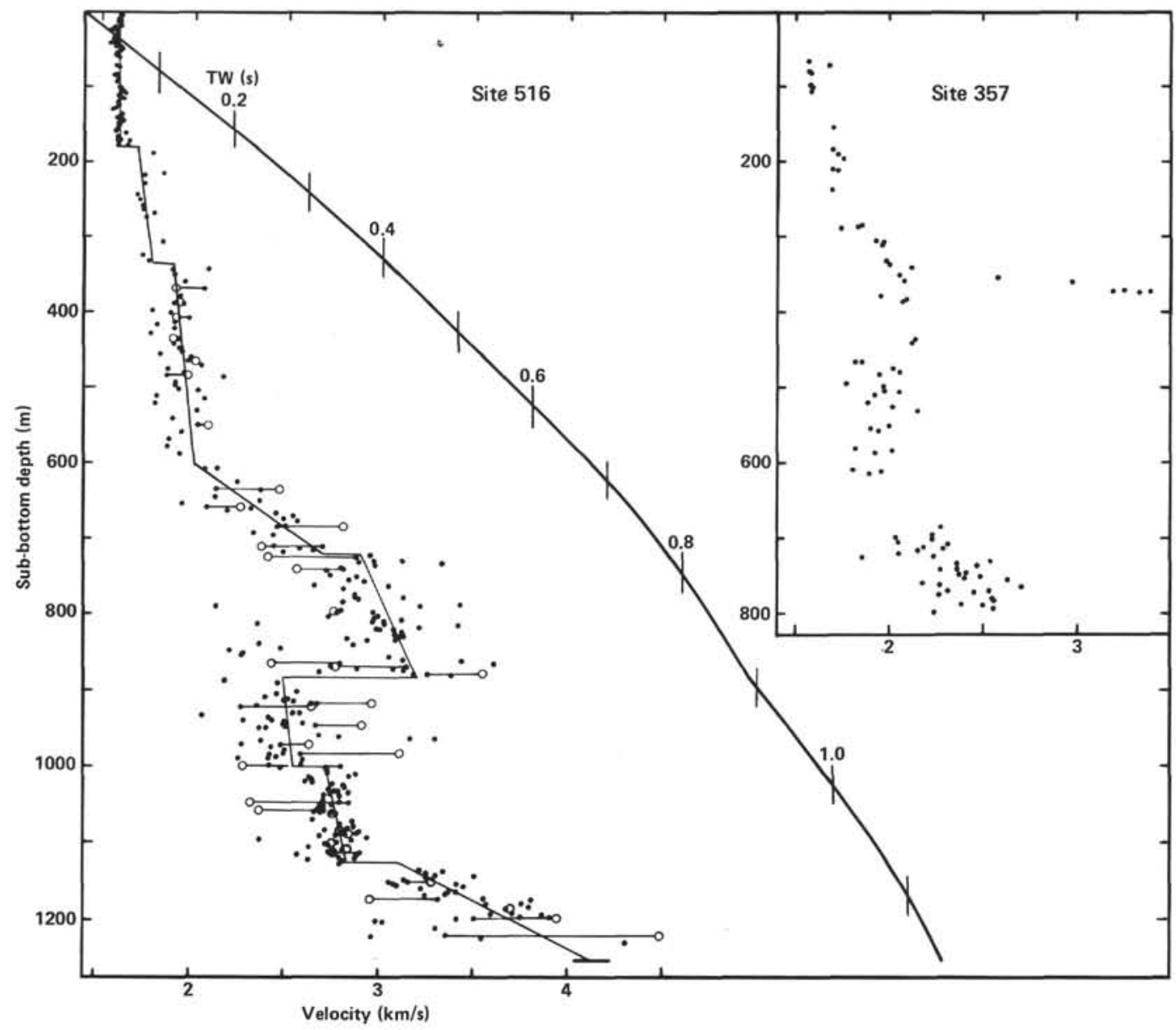

Figure 4. Shipboard measurements of horizontal p-wave velocity plotted against depth (solid circles), with derived velocity-depth and resulting time-depth models (thin and thick solid lines) used to connect drill site to reflection profiles. Inset are similar measurements for Site 357 (Supko, Perch-Nielsen, et al., 1977, p. 246). Open circles are vertical p-wave velocities at $0.1-\mathrm{kbar}$ confining pressure from Carlson and others (this volume). $\mathrm{TW}=$ two-way traveltime.

in Figures 2 and 3, form a loop from the Vema Channel across the crest of the Rio Grande Rise, a graben with guyots to either side. Profiles WSA9 and 10 appear to cross the steep slopes of two guyots on the southwestern side of the graben rather than their tops, resulting in reduced sub-bottom penetration, and diminish the value of the profiles for correlation purposes. Reflectors identified at Site 516 (Fig. 5) appear clearly on Profiles WSA11 and 13 on the northern shoulder of the Rise. WSA10 is separated from WSA 11 by a short data gap. Despite the difficulty of extending correlations across this gap, we start by considering these three profiles together, because WSA10 includes a useful traverse of a third guyot (the closest to Site 516 and a likely source for the middle Eocene Unit 4). Figures 9 and 10 are line drawings of profiles WSA13, and WSA10 and 11, respectively, illustrating the correlations proposed. Principal reflectors and sequence boundaries are defined in Figure 5.

\section{Basement Reflectors}

The identification on Profiles WSA13 and 11 of the basaltic basement Reflector A at Site 516 is reasonably unambiguous. The reflector is near horizontal in the southern part of Profile WSA13 (RN8500 to 9100) but dips northward in the northern part (RN9100 to 9700) and gently eastward over much of Profile WSA11 (RNO to 550). An important feature of Profiles WSA11 and 13 , however, is that other coherent, planar reflectors appear beneath Reflector A. Generally they dip in such a way that the sequence beneath Reflector A thickens downslope. The chemistry of the lavas and biostratigraphic age of the overlying sediments in Hole $516 \mathrm{~F}$ is compatible with an origin at the Mid-Atlantic Ridge crest (site chapter, Site 516, this volume), yet such subbasaltic reflectors are not typical of reflection profiles over most of the deep ocean floor. They do resemble dipping reflectors that have now been found along many continental margins (e.g., Hinz, 1981; Mutter et al., 1982). Where the uppermost parts of such sequences have been sampled, off Norway (Talwani, Udintsev, et al., 1976) and on Hatton Bank (Roberts, Schnitker, et al., 1982), they are subaerial or possibly submarine basaltic lavas interbedded with lesser amounts of shallow marine or subaerial sediments. At the margins, these sequences are considered to represent an initial phase of volcanism associated with continental separation, in which the spreading center is subaerial. 


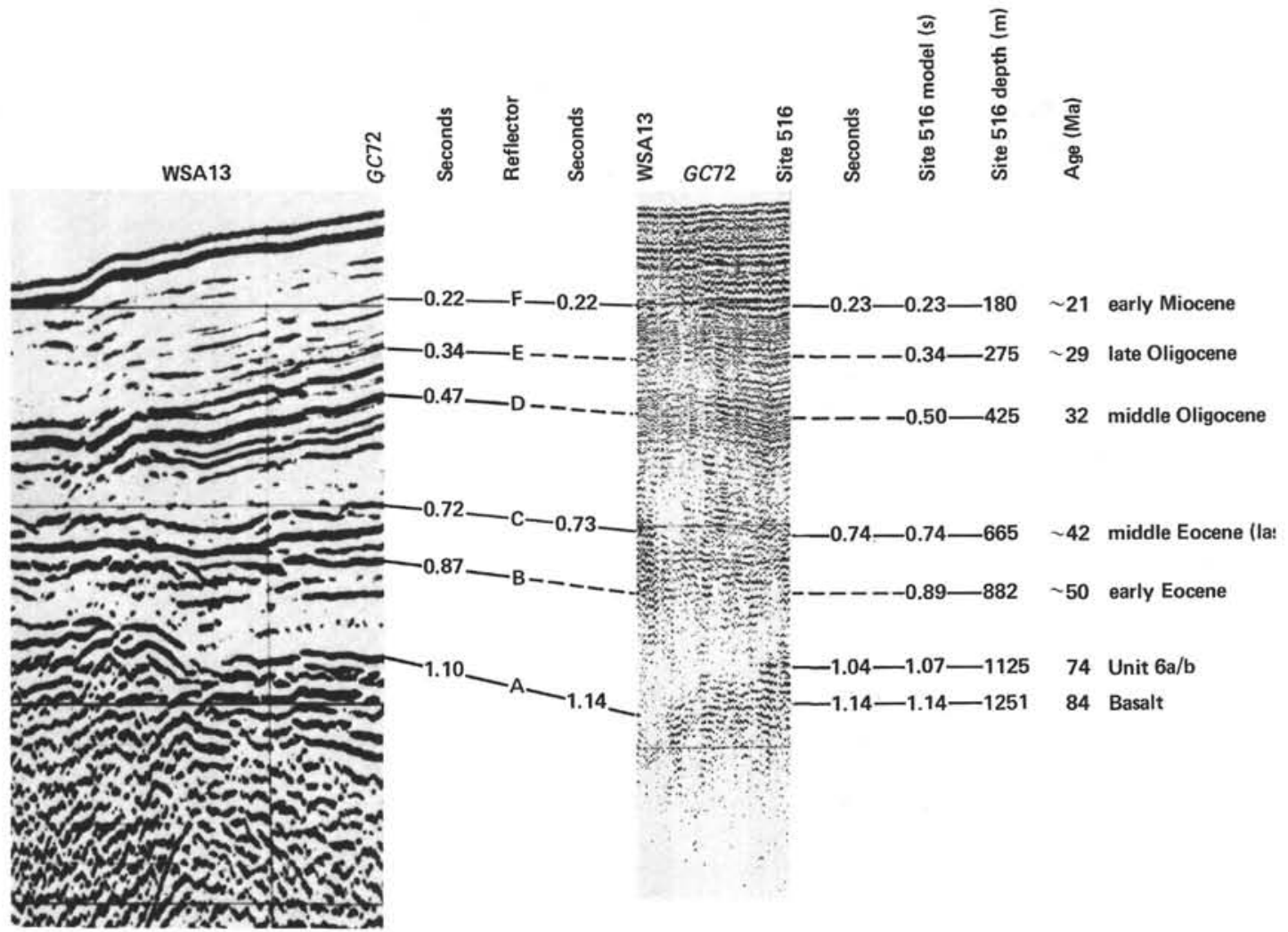

Figure 5. Correlation of Site 516 lithostratigraphy to Profile WSA13 by means of Leg 72 single-channel profile (for tracks, see Fig. 3). Lettered reflectors are seismic sequence boundaries. Dashed lines show inferred correlations where GC72 profile is obscured by nonprimary reflected energy.
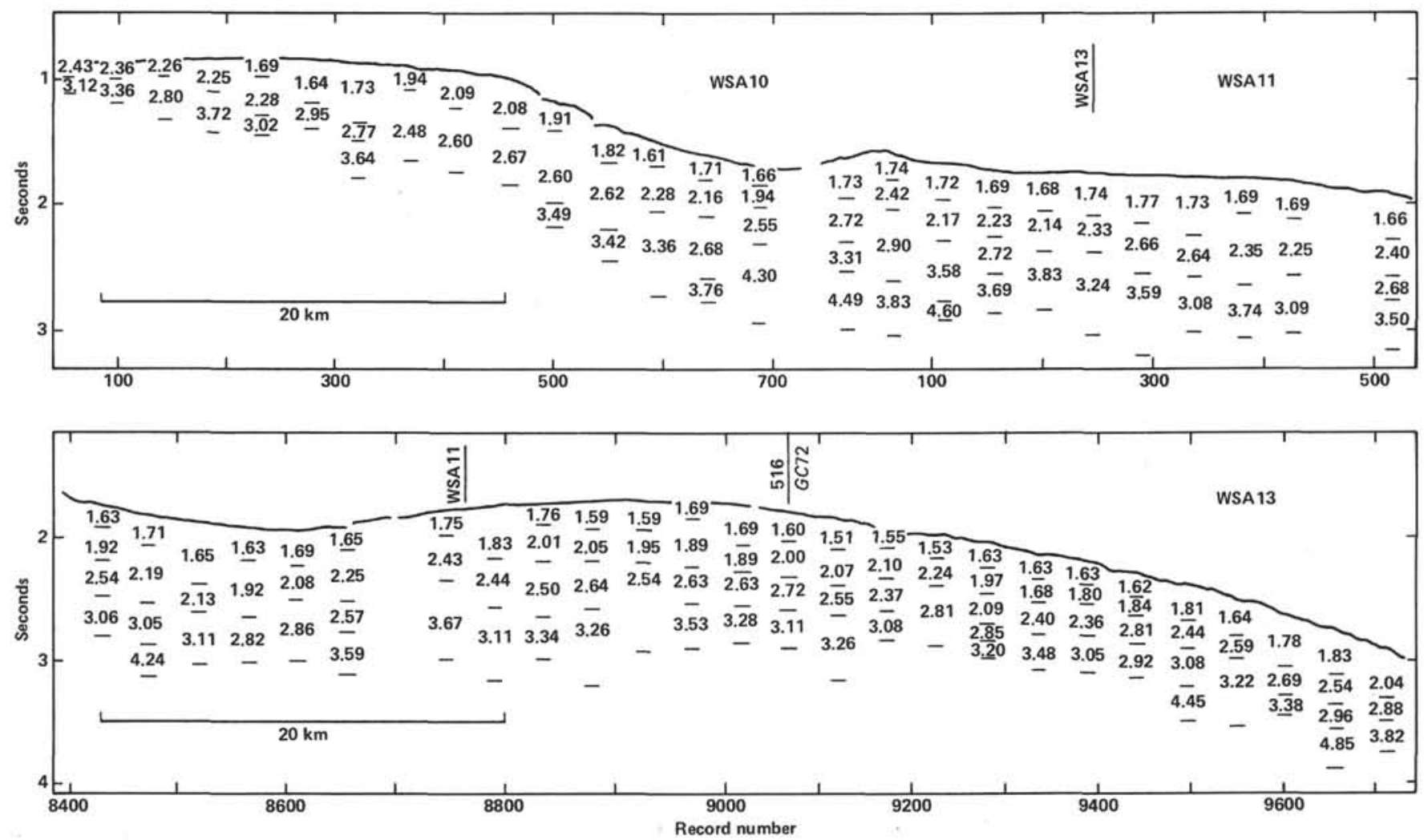

Figure 6. Interval velocities computed from common depth point stack of UTMSI multichannel Profiles WSA10 (part), 11 , and 13. 
P. F. BARKER, R. T. BUFFLER, L. A. GAMBOA

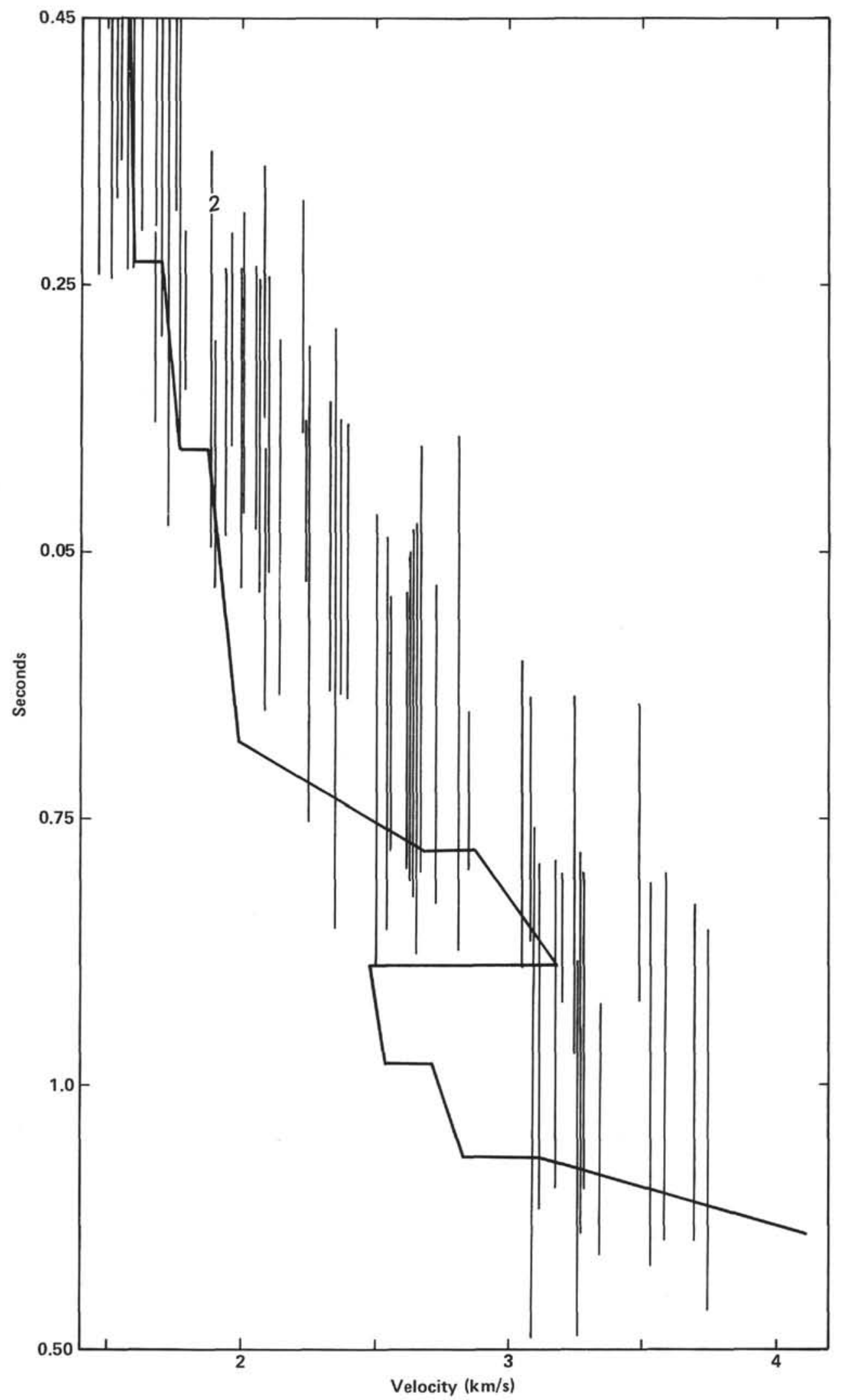

Figure 7. Interval velocities computed from velocity analyses of common depth point-stacked UTMSI Profiles WSA13 close to Site 516 and WSA11 where it intersects WSA13, compared with velocity model (thick line) derived from shipboard velocity measurements on samples from Hole 516F (see Fig. 4). 


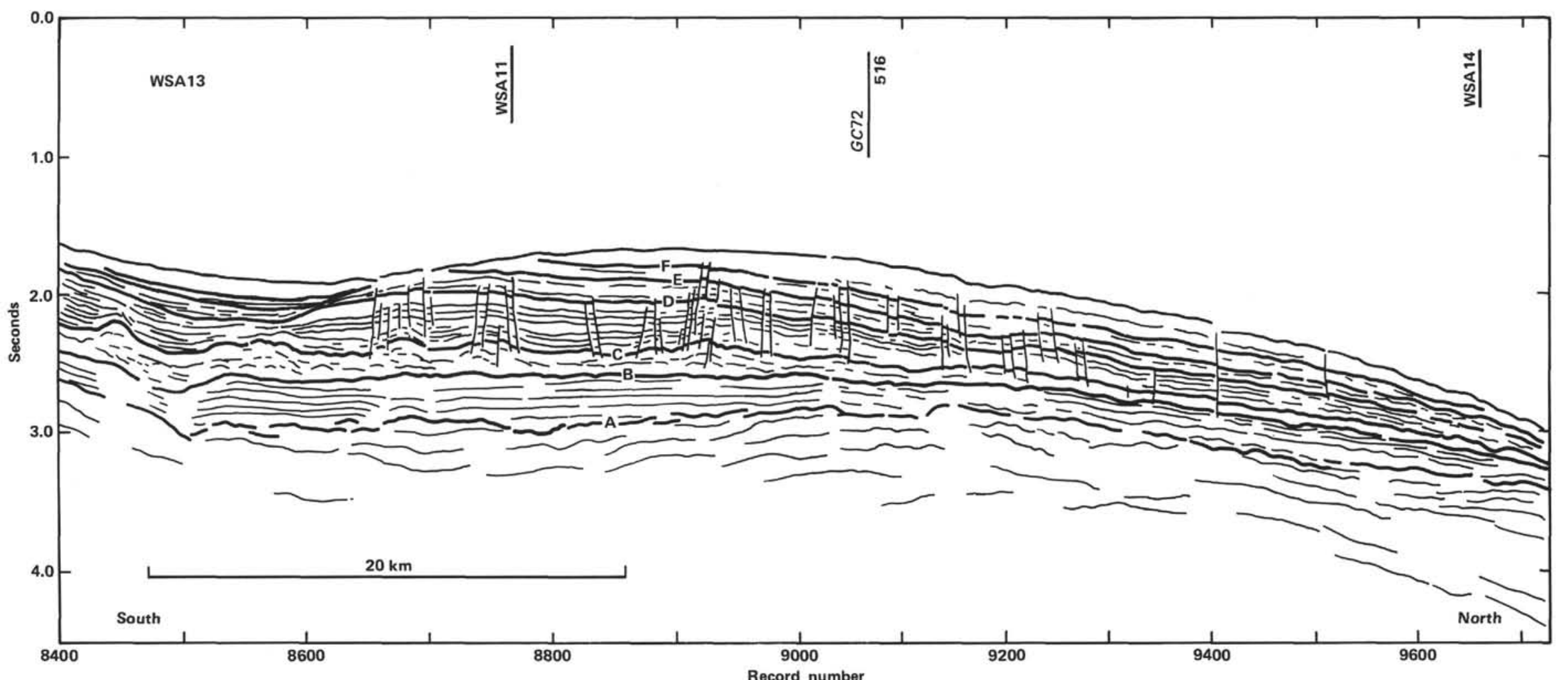

Figure 9. Line drawing interpretation of UTMSI Profile WSA13, forming a north-south section across the isolated bank on which Site 516 was located. See also Figure 8, backpocket. 


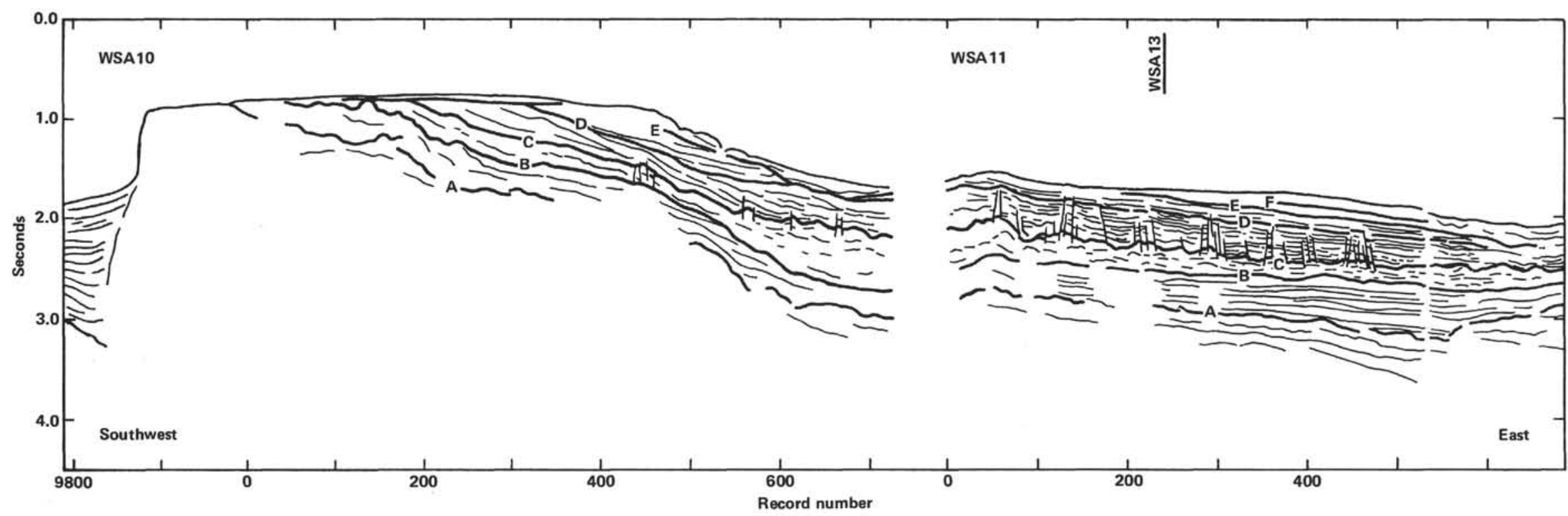

Figure 10. Line drawing interpretation of UTMSI profiles WSA10 (part) and WSA11, forming west-east section from the central graben of the Rio Grande Rise, over the flanking guyot and across the southern part of isolated bank on which Site 516 was located. See also Figure 8, backpocket. 
Hole $516 \mathrm{~F}$ drilled only $18 \mathrm{~m}$ into basalt and did not penetrate beneath the uppermost flow. It is not known whether the flow was erupted in air or water (site chapter, Site 516, this volume), but sediments directly overlying the basalt were very shallow marine (Milliman, this volume), subsequently becoming deeper quite rapidly. Thus, Site 516 appears to share with these continental margin occurrences an original environment of extension at a spreading ridge crest near sea level in which, for a period, lava production and sedimentation keep pace with thermal subsidence. The likely mid-oceanic origin of the Rio Grande Rise, remote from continental sediment sources, does not invalidate this comparison. The interbedded sediments on Hatton Bank are volcanogenic: the well-known tendency for seawater-magma interaction at low pressures to generate phreatic eruptions could provide sedimentary interbeds on the Rio Grande Rise as easily as at a continental margin.

The proximity of sea level is probably the key to the ultimate production of laterally extensive planar reflectors that distinguish this from the deep-water mid-oceanic ridge environment. Phreatic eruptions near sea level produce ash that is rapidly redistributed to the subhorizontal by wave action. Subaerial basaltic lavas flow greater distances than do deep-water pillow lavas (for indirect evidence of the extent of lava flow in deep water, see MacDonald et al., 1980). On the other hand, plateau basalts erupted far above sea level would be subjected to subaerial erosion, which would disrupt their lateral continuity, for a much greater time before submergence.

At continental margins the reflector sequence dips and thickens oceanward, a likely consequence of the oceanward migration of the eruptive center, the source of lavas and of some sediment and the locus of most rapid subsidence. Directly around Site 516 , the sequence below Reflector A dips and thickens northeastward, but the regional signficance of this is uncertain; on the opposite flank of the Rio Grande Rise, an identical sequence of reflectors (Profile WSA9, RN8100 to 8400, Fig. 8, backpocket) has components of dip and thickening to the southwest. In this latter area, in particular, the reflection profile gives a strong impression of overlapping lava flows, with the younger flows stepped back from the older flows in the downdip direction.

Also, the distribution of such sub-basement reflectors in Figure 8 (backpocket) is confined to those parts of the Rise sufficiently shallow now to have commenced a conventional oceanic subsidence curve (e.g., Tréhu, 1975; Parsons and Sclater, 1977) at or above sea level.

Reflector A is not planar everywhere. East of RN550 on Profile WSA11 (Fig. 10) and south of RN8500 on Profile WSA13 (Fig. 9) for example, it rises and becomes rougher. Such features are compatible with the origin suggested here; some subaerial topography with greater initial elevation may well have been created at the ridge crest, and may have partly resisted subsequent more prolonged subaerial erosion to become, ultimately, submarine elevations. In places, the basal sediments appear to lap onto this rising basement (RN8450 on Profile WSA13, for example). Further support for subaerial exposure is provided by the basal sediments of Hole 516F, which show an upward-decreasing noncarbonate component, and the oldest sediments sampled at Site 357 (Santonian-Campanian), which contain terrigenous (volcanogenic) material, again decreasing upward. It seems very likely, therefore, that parts of the Rio Grande Rise were subaerial for a short while after its formation. Barker (this volume) considers this aspect more quantitatively.

It is very difficult to trace any of the basement reflectors on Profiles WSA11 and 13 upslope into the guyot on WSA10 (Figs. 8, backpocket, and 10). Perhaps basaltic basement outcrops at the southwestern end of the guyot, whose flat top implies erosion to wave base. Much younger sequences are also apparently truncated there, and we associated this erosion with the middle Eocene tectonism, discussed in detail below. This middle Eocene episode and the data gap between profiles may not account for all of the difficulty in correlating Profiles WSA11 and 10; part of the difficulty might be the result of the variable acoustic character of Upper Cretaceous basement.

\section{Upper Cretaceous and Lower Tertiary Sediments}

The sequence of Cretaceous and lower Tertiary sediments of Units 5, 6, and 7 at Site 516 (Table 1 and Fig. 5), bounded by Reflectors A and B, is characterized by faint reflectors parallel or subparallel to the underlying basaltic basement and generally undisturbed by faulting (Figs. 9 and 10). Its different character in some places may be the effect of heterogeneity in the overlying sediments on the seismic pulse (for example, near RN200 and RN300 on Profile WSA11 in Fig. 8, backpocket). At the western end of Profile WSA11 and on the adjacent part of Profile WSA10, this effect is so magnified that correlation of these deeper beds across to Profile WSA10 becomes highly speculative. In our interpretation, this sequence thins upslope, and reflectors within it become less regular. In other areas, adjacent to more pronounced subaerial elevations, we would expect this basal sequence to thicken, because of enhanced sediment supply. Signs of onlap of this sequence onto basement at the southern end of Profile WSA 13, and the noncalcareous component in these sediments at Sites 357 and 516, are other indicators of subaerial basement. Reef formation around elevations, once volcanic activity had ceased and subsidence slowed, is another possible cause of uneven bedding and velocity heterogeneity in the sediments of this sequence along Profile WSA10. Their thickness may vary also because of erosion and slumping associated with the middle Eocene tectonic event, discussed in the next section.

\section{Middle Eocene Tectonism: "Midsection Domes"}

The middle Eocene Unit 4 at Site 516 contains slumps, partly volcaniclastic turbidites, and volcanic ash beds (see Bryan and Duncan, this volume), in addition to the pelagic calcareous biogenic sediments that form the remainder of the section. The amount of noncalcareous sediment decreases upward within Unit 4, the base of which is a $15 \mathrm{~m}$-thick slumped mass mainly com- 
posed of Maestrichtian chalk. The base corresponds approximately to Reflector B in Profiles WSA11 and 13, which marks the velocity inversion at $882 \mathrm{~m}$ (Figure 5).

Silicification, which raised p-wave velocities of Unit 4 limestones, has also migrated a small distance downward into Unit 5, producing a slight discrepancy between the lithostratigraphic and acoustic boundaries. The upper part of Unit 4 is gradational into Unit 3, but the highest "ash" bed at $665 \mathrm{~m}$ corresponds approximately to Reflector C. Similar, partly volcaniclastic middle Eocene sediments were found at Site 357 (Supko, Perch-Nielsen, et al., 1977). Discontinuous coring and imprecise biostratigraphic control hinder comparison between sites, but the equivalent unit is apparently thinner than at Site 516 and covers a shorter period. The associated p-wave velocity excursion at Site 357 is also less prominent (see Figure 4 inset).

The sequence bounded by Reflectors B and C stands out on Profiles WSA11 and 13 and contains the enigmatic "midsection domes." When Site 516 was originally chosen, partly on the basis of single-channel Vema Profile 26-06 (Fig. 11), the domes were thought to indicate igneous basement. Because Site 516 actually sam- pled only the lower flank of one of the less well-developed of these domes, their precise nature remains uncertain, but their distribution and character on Profiles WSA11 and 13 provide some clues.

The sequence is evenly bedded away from the domes, but chaotically bedded within them. It is thicker, and the domes more numerous and better developed, in the direction of the crest of the Rise on all profiles. The most extensive development flanks the data gap between Profiles WSA10 and 11, and the domes largely die out farther upslope on WSA10 (Fig. 10). The p-wave velocity structure within the domes appears to differ only slightly from that of the adjacent, evenly bedded parts of the same sequence; little "pull-up" of the basement reflector beneath them is detected (e.g., see Profile WSA13 between RN8500 and 9000, Fig. 8, backpocket). Nor are the reflectors from underlying sediments or basement offset beneath the domes; the obvious faulting in the sediments overlying the domes appears to start within the dome sequence and propagate upward, reaching the seabed in places. The faults could therefore result from processes such as differential compaction within and around the domes.

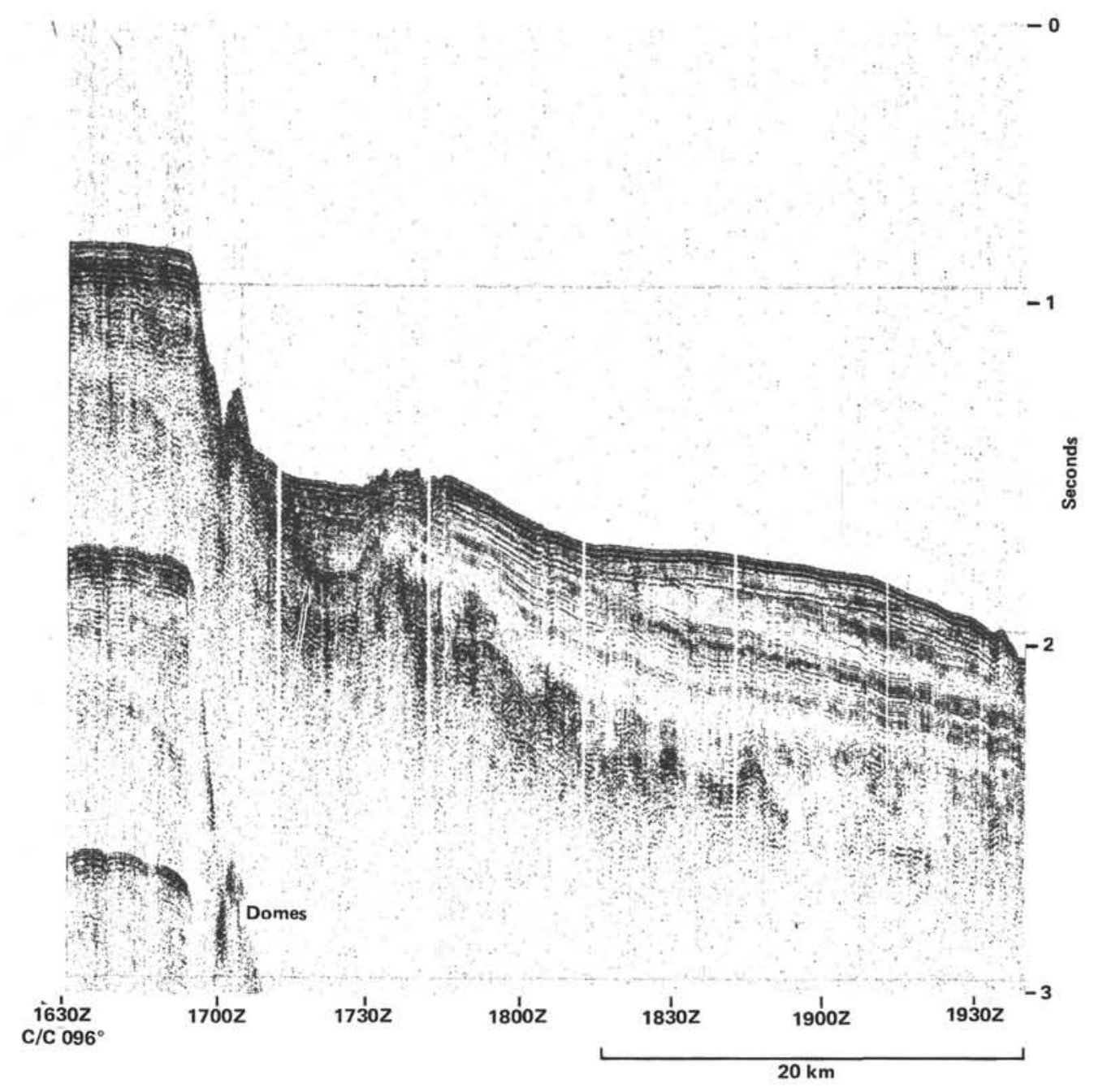

Figure 11. Vema 26-06 single-channel profile Record 819 across guyot and northern flanks (shown in Fig. 3 as $\mathrm{AA}^{\prime}$ ). This profile was used in the initial location of Site 516 . 
We suggest that the domes formed around the toes of a series of submarine sediment slides and slumps, caused by the middle Eocene uplift of the crest of the Rise, which both steepened the paleoslope and ultimately loaded the outer shelf with the products of subaerial erosion and/or erosion above wave-base, after the Rise became reemergent. Clearly a considerable amount of sliding took place onto the shoulder of the Rise where Site 516 lies, from the crestal area crossed by Profile WSA10 (although Profiles WSA10, 11, and 13 do not form a true dip section across the Rise, which here strikes approximately northeast-southwest). At Site 516, the $15-\mathrm{m}$ thick allochthonous Maestrichtian carbonate slide at the base of Unit 4 is lithologically identical to sediments now $140 \mathrm{~m}$ (then $230 \mathrm{~m}$ ) deeper in the section. Thus, at least $230 \mathrm{~m}$ of ooze and chalk probably slid from the upper slopes of the crestal area onto the northern shoulder of the Rise during the initial tectonism. No comparable slides are found higher within Unit 4, which contains pelagic biogenic sediments with interbedded turbidites of mixed (calcareous and volcanogenic) composition. Closer to the crestal region, however, where the middle Eocene sequence is thicker and the domes more numerous, later slides could have occurred.

By the nature of the slides, their base will usually be an unconformity, although stratigraphically this is hardly detectable at Site 516. Upslope from Site 516 where the slide may have originated (Fig. 10), the local removal of $230 \mathrm{~m}$ of ooze and chalk, modified by subsequent burial, would create $0.10-0.15 \mathrm{~s}$ of relief on Reflector B. The relief is considerably greater in places, suggesting that faulting is also involved (for example, at RN040 on Profile WSA11, Fig. 10). If slumping alone produced this relief, then sediments more consolidated than the Maestrichtian chalk at the base of Unit 4 at Site 516 (which had slumped more coherently from deeper in the original section) could lie within the cores of the better-developed domes.

Subsequent pelagic deposition probably preserved the relief of the toes of the slides, and turbidites either flowed or were ponded between them. The slides would have been "preconsolidated" to some extent; measured porosities at $230 \mathrm{~m}$ in Hole $516 \mathrm{~F}$ were about $10 \%$ less than at the seabed, so that subsequent compaction under load could have been less in the slides than nearby. Preconsolidation would preserve slide topography and even, by faulting, propagate it upwards in the reflection profiles to some extent, exaggerating the slides' original size.

Alternative explanations of the nature of the middle Eocene sequence, where it is better developed away from Site 516, are difficult to construct. We don't think the domes are cored by sills or laccoliths, because the sequence is incoherent throughout with no prominent localized reflectors, because "pull up" is small and because the domes disappear towards the crest of the guyot where magmatic activity should be concentrated. Reefs also are unlikely for this reflector geometry except as allochthons; benthic foraminifers indicate bathyal in situ depths (Tjalsma, this volume). Postdepositional deformation, either as diapirism caused by local pore-fluid overpressures or as overthrust faulting under upslope load above a basal décollement, may have made some secondary contribution to the incoherence of the sequence, but cannot replace the primary mechanism of sediment sliding following the differential uplift of the Rise crest.

On the southwestern flank of the Rise, the middle Eocene sequence is less well displayed. The seismic section at RN8300 on Profile WSA9 (Fig. 8, backpocket) is very similar to that at RN9500 on Profile WSA13; the middle Eocene sequence (0.55-0.64 s sub-bottom) is relatively thin despite the proximity of another guyot. Extension of deeper reflectors northeastward beneath the guyot are only faintly suggested, at best, and "midsection domes" are poorly developed.

Volcanism and faulting during the middle Eocene tectonic episode also affected the distribution of slides on the flanks of the Rio Grande Rise. These processes exert a large measure of control on subsequent sedimentation, to the present day, however, so we will also discuss them in subsequent sections.

\section{Middle Eocene Tectonism: Volcanism and Faulting}

Profile WSA10 crosses a well-developed graben, with obvious rotated fault blocks, between RN9450 and 9900 (Fig. 8, backpocket). All these blocks, however, appear to be downthrown to the southwest, and it is uncertain whether the southwestern side of the graben lies at RN9300 or elsewhere. Profiles WSA9 and 10 probably cross the steep slopes of two guyots on the southwestern side of the graben, but bathymetric control in the region is imprecise. The continuity of the graben, however, is in little doubt; it strikes approximately west-northwesteast-southeast across the entire Rise and is seen both on L-DGO profiles crossing the crest (C1102, Record 185, for example) and on the Glomar Challenger profile leaving Site 516. Within the graben on Profile WSA10 (Fig. 8, backpocket) the rotated fault blocks show a prominent basal reflector, approximately planar but with slight small-scale irregularity. The overlying sediments all thicken northeastward and are clearly syntectonic or post-tectonic (see below). No pretectonic sedimentary layering can be seen on or around any of the blocks. The adjacent western end of the guyot (RN9900 on Profile WSA10, Fig. 10) has igneous basement exposed at the seabed by subaerial erosion, according to our interpretation. We suggest therefore that graben formation and other block faulting were late stage, after uplift above sea level and some planation of the crestal region (including removal of the sedimentary cover on the fault blocks) and thus probably after the majority of the slides had occurred. Any faulting beneath the thickest slide accumulation (RN700 on WSA10) would be of the same age.

In regard to the question of local middle Eocene volcanism, we now have plentiful evidence of the middle Eocene uplift. This uplift seems most probably thermal and, like other off-axis "hot-spot" occurrences, was probably accompanied by volcanism, typically alkalic. The present questions are, therefore, how much volcanism occurred and exactly where did it occur. The exist- 
ing geologic evidence, although it supports the existence of volcanism, is somewhat ambiguous (for a discusson see Bryan and Duncan, this volume; Barker, this volume). The volcanogenic component of Unit 4 is at most about $20 \%$ (of $240 \mathrm{~m}$, covering $8 \mathrm{Ma}$ ); even if it were all erupted during the middle Eocene, the amount does not suggest a dominant role for middle Eocene volcanism on the crest of the Rio Grande Rise. The middle Eocene sequence does not thicken appreciably upslope on Profile WSA10 (Fig. 10), and there seems no strong a priori geologic argument for revising our interpretation (speculative though it undoubtedly is, because of the confusing reflection character). The other elevations (Profiles WSA9 and 10, and Fig. 8, backpocket) on the southwestern flank of the graben do not show any similar deep, dipping structure, truncated at or near the present seabed, so their origin is uncertain. Single-channel profiles crossing other guyots also lack penetration. Elsewhere on the Rise, therefore, the question of abundant volcanic activity is still unanswered. The isolated guyot on the lower southeastern flank of the Rise, for example, could be a mid-Eocene volcano. The least depth of water above it is similar to that of the Rise crest, suggesting a similar post-middle Eocene subsidence history.

\section{Late Eocene to Recent Sedimentation}

The sediments above Unit 4 at Site 516 show continuous pelagic deposition, except for a hiatus of about $5 \mathrm{Ma}$ in the late Miocene (Table 1 and site chapter, Site 516, this volume). Close to Site 516, Profile WSA13 (Fig. 9) also gives this impression; sediments are draped conformably over the uneven top of Unit 4 (Reflector C) and disturbed only by minor faults. Farther away from the site, however, the profiles show that Site 516 lies on an isolated bank, surrounded by areas of sparser and less continuous deposition. The present sedimentary regime is illustrated by a $3.5-\mathrm{kHz}$ profile obtained during Glomar Challenger's departure from Site 516 (Fig. 12). Pinger penetration (2 depth intervals) is $60 \mathrm{~m}$ into upper Miocene oozes. These uppermost sediments at the site thin westward, and the depositional regime is replaced by one essentially erosional on the lower slopes of the adjacent guyot.

All the sediments above Reflector $\mathrm{C}$ thin downslope on Profile WSA13 (Fig. 9), although at Site 357 (also downslope, but not close to WSA13) the principal thinning occurs in the Oligocene and upper Eocene sediments (nannofossil Zones NP 24 to 17), between Reflectors C and E. Southward from Site 516 on WSA 13, Miocene and younger sediments outcrop at the seabed, on the flank of a gentle bathymetric trough, separating the site from the guyot. A paleotrough is buried beneath the bathymetric trough. The diachronous unconformity (toplap beneath, onlap above) on its northern flank is an earlier analog of the seabed, possibly as old as the middle Oligocene. A similar buried trough on Profile WSA10 (RN600 to 700, Fig. 10) is less confidently correlated across the data gap from WSA11, but appears to be of the same age. Although sediments older than midOligocene (Reflector D) appear conformable, the topo- graphic trough in which they were deposited is at least as old as late middle Eocene (Reflector C) on both profiles and the C-D sequence is thinner beneath the trough than elsewhere. The significance of all this becomes apparent on examination of Figure 13. McDowell and others (1977) and Johnson and Peters (1979) have shown that deep canyons dissect the northern slope of the Rio Grande Rise. The canyon heads connect with shallow troughs on the shoulder of the Rise where Site 516 is located. Examples of these canyons downslope from Site 516 may be seen at RN1000 on Profile WSA15 and RN1400 on Profile WSA16 (Fig. 8, backpocket). Using the considerable single-channel coverage of this area (e.g., Fig. 11) in addition to the multichannel profiles, we can show that the shallow troughs themselves originate along the base of the guyot. Thus, the currents that cut the canyons are at least as old as mid-Oligocene, as Johnson and Peters (1979) speculated, but these currents were probably channelled near their source by still older typographic depressions (late middle Eocene, Reflector C).

In order to understand the nature and origin of the currents, we must also consider sedimentary processes in the crestal area. On the flat top of the guyot shown on Profile WSA10 (RN9900 to 0350, Figs. 8, backpocket, and 10), all sediments older than mid-Oligocene (Reflector D) and possibly as young as late Oligocene (Reflector E), are truncated and unconformably overlain by only a thin flat-lying sequence. According to our interpretation, however, middle Eocene (Unit 4) sediments would originally have been progradational, and it is not possible to distinguish between erosion and nondeposition from the reflection profile alone. Post-middle Eocene sediments from this area (RN200 to 600, Profile WSA10) show a complex mixture of apparently onlapping, offlapping, and toplapping reflection terminations that we interpret as the results of local variations in current strength and biogenic productivity in a slope environment, rather than from complex vertical tectonic movements or large sea-level fluctuations.

The present elevation of the guyot is consistent with steady thermal subsidence after a tectonic culmination in the mid-Eocene during which large areas of the crest of the Rise would have been subaerial (Barker, this volume). Horizontal truncation of sediments at the guyot top and the presence of limestone clasts within turbidites in Unit 4 both suggest erosion above wave base, but the time at which the crest finally subsided through sea level is uncertain. The youngest turbidite within Unit 4 at Site 516 is late middle Eocene (site chapter, Site 516, and Tjalsma, this volume). This deposit need not indicate the end of unstable conditions at the guyot margin, or of subaerial erosion, however; by then, a channel system bypassing Site 516 may have developed. Final subsidence through sea level could have been as late as the early Oligocene (Johnson and Peters, 19/9: Barker, this volume). More importantly, however, the (presumed biogenic) flat-lying sediment cover on the guyot is very thin (less than $100 \mathrm{~m}$ ), whereas post-Eocene sediments at Site 516 are $530 \mathrm{~m}$ thick and at Site 357 about $250 \mathrm{~m}$ thick. We doubt that this discrepancy 
East

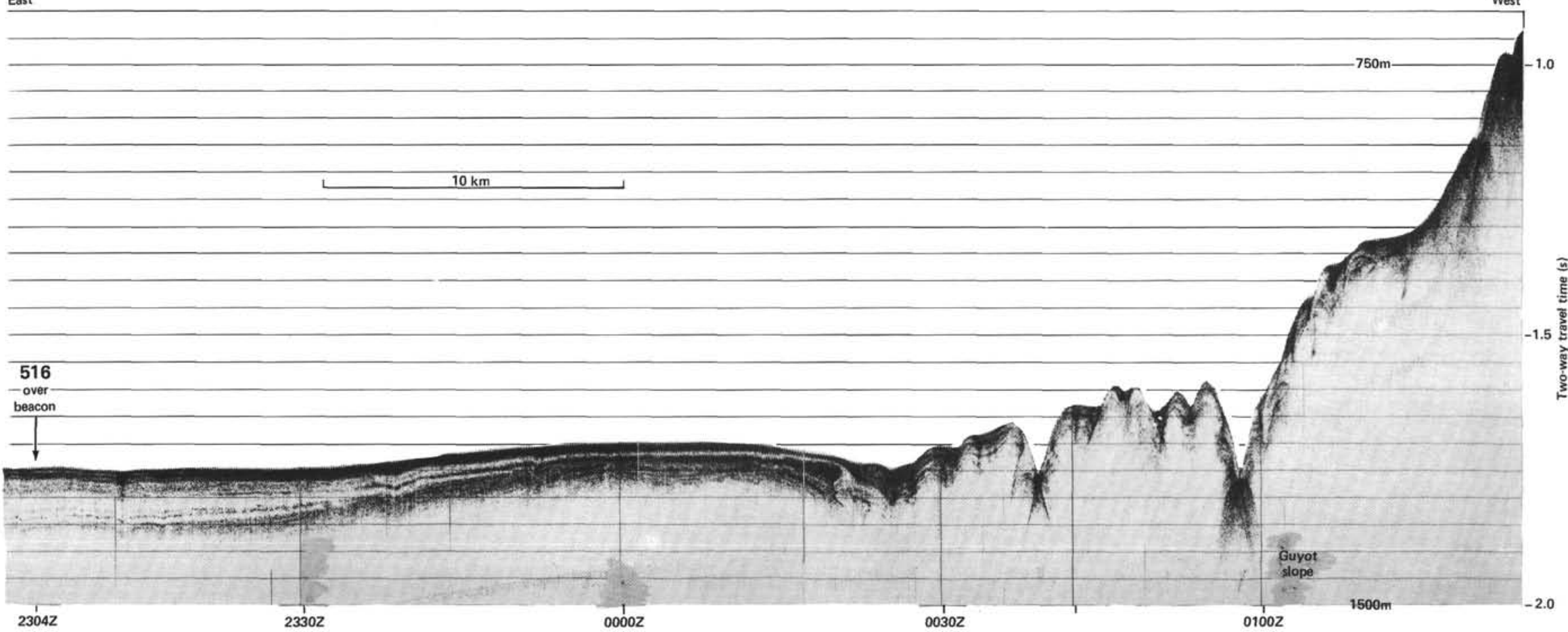

Figure 12. Pinger profile ( $3.5 \mathrm{kHz})$ obtained during the westward departure of the Glomar Challenger from Site 516 (for location, see Fig. 3). 


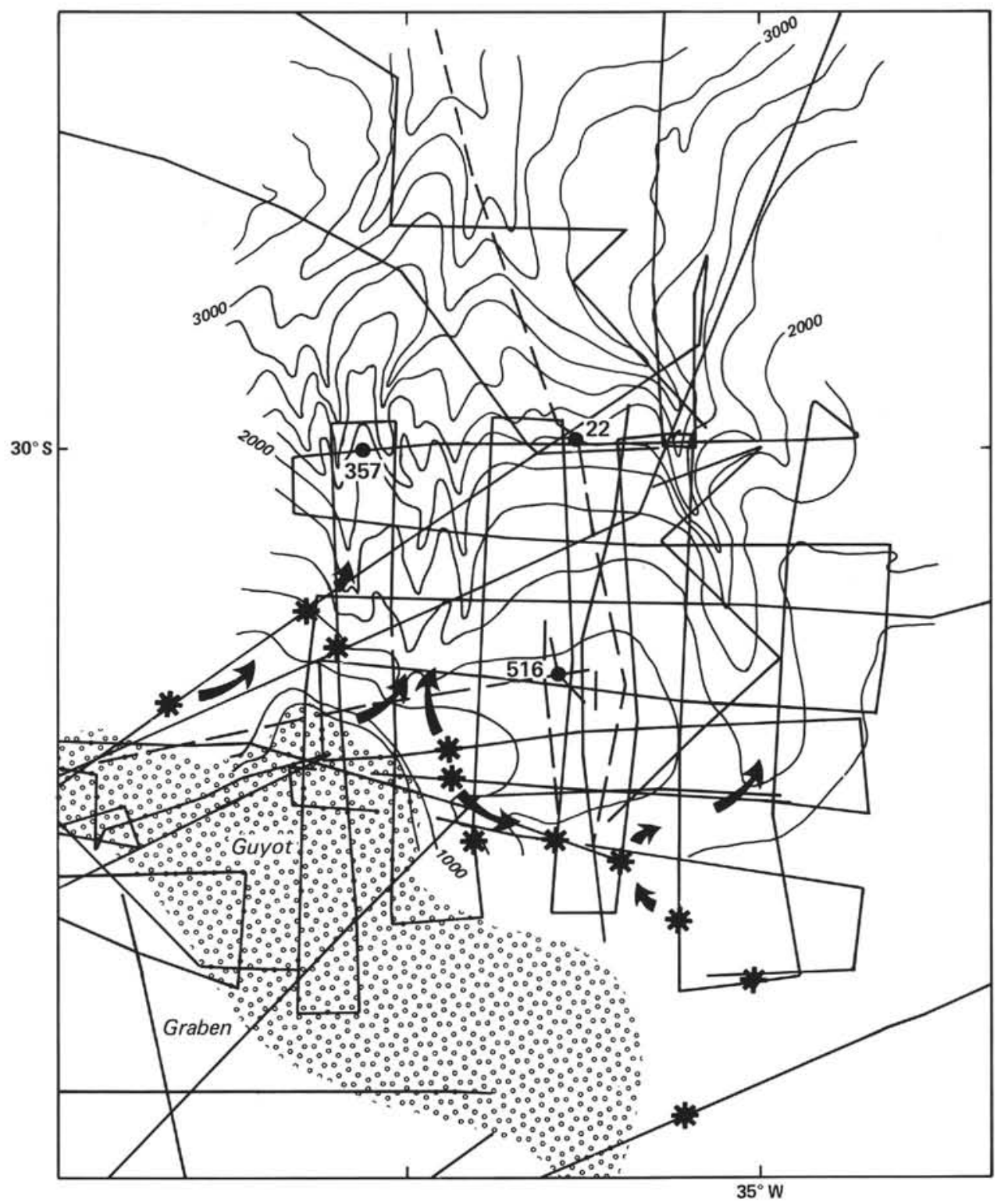

Figure 13. Relationship between channels and canyons on the northern slope of the Rio Grande Rise and (starred) buried post-middle Eocene troughs flanking the crestal guyot. Bathymetry (200-m isobaths) is from McDowell and others (1977).

results from regional differences in biogenic productivity; indeed, we would expect upwelling around the topographic elevations of the Rise, leading to locally enhanced productivity. Rather, we think that, since the submergence of the guyot, most of the pelagic debris falling on it has been swept off to either side by bottom currents, leaving perhaps only a lag deposit of macrofossils, large foraminifers, and so forth. The displaced portion would have continued the progradation of the northeastern flank of the guyot and contributed an initial load to the density currents responsible for canyon cutting to the north. Thus the mode of deposition on the northern shoulder of the Rise gradually changed. During the middle Eocene, turbidites were being deposited at Site 516; in view of the isolated position of the site (Figs. 1 and 13), this deposition suggests that turbidites were not then being channelled to any great degree. In- creasingly, however, turbidites became channelled and bypassed Site 516. By winnowing and entraining the fine fraction of the pelagic sediments along their path, they slowly created the topography that itself increased the extent of the channelling. The initial load at this time (late Eocene, early Oligocene?) still came from subaerial erosion of the guyot but later (after submergence) came from sediment winnowed from the top of the guyot by strong bottom currents. Where the slope steepened, below $2000 \mathrm{~m}$ present depth, winnowing became actual erosion, and canyon cutting started. It is difficult to say exactly when this happened, except that at any time after the middle Eocene, once channelling had commenced, erosion seems possible. Canyon cutting may have become more effective after the major invigoration of the thermohaline circulation in the earliest Oligocene (Benson, 1975; Kennett and Shackleton, 1976). 
Thus, ultimately, the middle Eocene tectonism caused the dissection of the lower slopes of the Rise. Was there a more direct tectonic contribution to the creation of the now-buried trough around the base of the guyot? The single-channel profiles, which are the great majority of those used in Figure 13, only penetrate to the top of Unit 4 (e.g., Fig. 11). Only near RN040 on Profile WSA11 (Fig. 10) is it apparent that the trough reflects basement topography. Even on this multichannel profile, the quality of reflections from deeper layers is poor, but it is possible that the trough was created partly by faulting. The most likely correlative would be the "late-stage" faulting of rotated blocks within the graben already discussed; an additional, outer fault, also downfaulted to the southwest, would depress the rim of the guyot. The likely age of such faulting would thus be late middle Eocene.

The same sequence of subaerial erosion followed by bottom current winnowing also controlled sedimentation within the graben (Fig. 8, backpocket), where Profile WSA10 shows clearly that the major sediment source has been the guyot to the northeast. Thus, here also, sedimentation that probably began in the late middle Eocene with sediments derived from the guyot by subaerial erosion, while downfaulting was still taking place, continued to the present day by the action of bottom currents on the submerged guyot top. Because of differential compaction of the sediments and the diffracted energy from the main scarp, it is impossible to tell on WSA10 at what depth within the sediment pile in the graben the process changed.

\section{Regional Considerations}

It is not possible to extend the above analysis in any detail to the remainder of the Rio Grande Rise and its surroundings because of the sparse seismic coverage (Fig. 2) and the intervention on most profiles of basement highs and areas of nondeposition or erosion. Nevertheless, some general comments can be made on the history of the Rise as an influence on circulation and as a source of sediment.

First, the extent of the dipping sub-basement reflectors on the multichannel profiles, in combination with other evidence, implies that most of the presently elevated part of the Rise (say, inside the present $3500 \mathrm{~m}$ contour in Fig. 1) has been abnormally elevated since its formation in the Late Cretaceous. This conclusion cannot necessarily be extended to the other parts of the Rise to the north and east, although the presence of a Campanian(?) coquina $2240 \mathrm{~m}$ below sea level at Site 21 suggests that it holds there also (Maxwell, Von Herzen, et al., 1970). The reflection profiles provide further support; pre-middle Eocene sediments on the lower flanks of the Rise and in adjacent basins (Gamboa et al., this volume) appear to be thicker than on the Rise itself. The Rise is essentially plateau-shaped, with steep sides and (except for the guyots) a flat top. This characteristic is better illustrated by the Glomar Challenger profile between Sites 515 and 516 (Fig. 14, backpocket). Profiles WSA8, 9, and 16 do not show this characteristic nearly as well, because they are oblique to the lower slopes of the Rise. As expected, the steep flanks of the Rise show the most prominent signs of erosion or nondeposition. Along the Glomar Challenger profile, sedimentation is discontinuous between 2000 and $3600 \mathrm{~m}$ water depth, at least partly because of the canyon cutting. However, this depth range shows similar dissection all around the Rise, even at an isolated topographic high on its eastern extremity (Profile RC1102, R166 through 170, not shown), where the upslope creation of density currents cannot occur. Thus, the dissection may be partly scour by contour currents, intensified around the obstruction of the Rise. The depth range is that of the southwardflowing North Atlantic Deep Water (Barker et al., 1981, fig. 2; Johnson, this volume).

Figure 14 (backpocket) illustrates a direct section between Sites 515 and 516, passing across the northern shoulder of the Rise. Post-Eocene sedimentation at Site 515 is probably controlled by Antarctic Bottom Water (AABW) flow through the Vema Channel (site chapter, Site 515 , this volume), but thin calcareous layers within post-Pliocene sediments may be turbidites that originated on the northern shoulder of the Rise (Shor et al., this volume). Strong bottom currents within the Vema Channel create hiatuses, and manganese nodules or encrustations are common (for details, see Johnson, this volume). Sedimentation on the Vema Terrace, the eastern border of the Vema Channel, is commonly hemipelagic clay with displaced Antarctic diatoms (Johnson, this volume); its chaotic acoustic character (Profiles WSA7 and 16, Fig. 8, backpocket) is typical of a variable, high-energy depositional environment. Farther from the Vema Channel, more evenly bedded overlying sediments may be turbidites derived from the Rio Grande Rise. It is more difficult to imagine, however, how turbidity currents from the Rise can "jump" the Vema Channel, to be deposited on the western side, without being at least partly entrained within AABW and transported northwards. We suggest that Figure 14 (backpocket) also shows a crossing of the Vema Channel. An eastward swing of the Channel around the northern end of the Rio Grande Rise has not previously been noted, but the similarities in the depth of the trough $(4850 \mathrm{~m}$ at approximately 1750,9 April) and its asymmetric section, as well as the strong resemblance of the terrace (between 1830 and 2030) to the Vema Terrace, are most convincing. Presumably, the topography of the Rio Grande Fracture Zone along $28.5^{\circ} \mathrm{S}$ (Gamboa and Rabinowitz, 1981) has controlled the position of the channel. By the appearance of the deeper reflectors, which may be dated by correlation with Site 515 , current flow along the channel has been vigorous since at least the mid-Oligocene and probably for longer. If the channel is continuous with the Vema Channel, as we suggest, then direct turbidity current flow from the Rise to Site 515 involves displacement of AABW. Whether the actual path is direct, through displacement, or is indirect, via mixing and entrainment or via deposition and reerosion on the terrace, cannot be resolved here.

\section{CONCLUSIONS}

Despite the sparse and uneven distribution of reflection profiles (particularly multichannel profiles) over the Rio Grande Rise, and the limited amount of control 
provided by DSDP sites, a series of conclusions can be drawn from these data concerning the tectonic and sedimentary evolution of the Rise. We want to emphasize that some of these conclusions are speculative, because of data gaps and ambiguities. The analysis mostly concerns the northern flank of the Rise, where both seismic and geologic cover is most dense, with some extrapolation to the remainder of the Rise.

1) A sequence characterized by dipping planar reflectors occurs beneath basaltic basement at Site 516 and over a significant part of the Rio Grande Rise. By analogy with similar sequences found at some continental margins, the sequence represents volcanism and sedimentation at or directly above sea level. Other parts of the Rise, also probably formed subaerially, are rougher and lack deeper reflections.

2) Upper Cretaceous and lower Tertiary sediments lie conformably upon the proposed near-sea level basement and lap onto the rougher elevations, indicating steady subsidence of the Rise.

3) Middle Eocene "'midsection domes" near Site 516 are interpreted as submarine slides caused by uplift and tilting centered on the present crest of the Rise. During the same tectonic episode, the central part of the Rise was lifted above sea level. The guyot upslope from Site 516 was planed off by subaerial erosion, exposing basement rocks in the center. This center was then downfaulted to produce the present graben and the rotated blocks within it. Any associated volcanism was probably of minor importance, leaving no clear imprint upon the reflection profiles.

4) Post-middle Eocene sedimentation at Site 516 regained its wholly pelagic character, but this may not fully reflect the sedimentary environment of the Rise, because turbidity current activity probably did not cease but bypassed the site by means of shallow channels directed by the deposition of slide debris. These currents were probably loaded initially by subaerial erosion products and then, after the crest of the Rise had again subsided below sea level, by biogenic sediment winnowed from the top of the guyot by strong bottom currents. These density currents also created the canyons downslope from Site 516, and other winnowed debris from the top of the guyot continued the progradational growth of its outer margin.

5) North of Site 516, the slope of the Rise is dissected by canyons, but the slopes between about 2000 and $3600 \mathrm{~m}$ show some signs of erosion all around the Rise, including areas where density current production upslope is impossible. The erosion probably results partly from scour by currents within North Atlantic Deep Water, intensified by the obstruction of the Rise.

6) The Vema Channel and Vema Terrace extend around the northern side of the Rio Grande Rise. Turbidite deposition on the upper part of the Terrace can be demonstrated from the reflection profiles, but direct turbidity current flow from the slopes of the Rise across the Channel into the southern Brazil Basin, unmodified by AABW flow along the Channel, seems less likely.

\section{ACKNOWLEDGMENTS}

We are grateful to the ships' companies of Glomar Challenger and Fred H. Moore for their assistance with the collection of some of the seismic reflection profiles considered here and to many individuals at the IPOD Site Survey Data Bank and the Deep Sea Drilling Project for the many ways in which they have willingly and effectively helped us during this investigation. Ian Hill, Mike Brooks, and, particularly, Dave Johnson and Bill Coulbourn made many helpful suggestions that have improved the text.

Lamont-Doherty single-channel profiles, considered during this study but not displayed, are available from World Data Center A. Glomar Challenger profiles for Legs 36, 39, 71, 72, and 73 may be obtained from the Data Manager, DSDP, and UTMSI multichannel profiles are available from the IPOD Site-Survey Data Bank at LamontDoherty Geological Observatory.

\section{REFERENCES}

Al-Chalabi, M., 1979. Velocity determination from sesimic reflection data. In Fitch, A. A. (Ed.), Developments in Geophysical Exploration Methods: London (Applied Science Publishers), pp. 1-68.

Barker, P. F., Carlson, R. L., Johnson, D. A., and Shipboard Scientific Party, 1981. Deep Sea Drilling Project Leg 72: southwest Atlantic palaeocirculation and Rio Grande Rise, tectonics. Geol. Soc. Am. Bull., 92:294-309.

Barker, P. F., Dalziel, I. W. D., et al., 1977. Init. Repts. DSDP, 36: Washington (U.S. Govt. Printing Office).

Benson, R. H., 1975. The origin of the psychrosphere as recorded in changes of deep-sea Ostracode assemblages. Lethaia, 8:69-83.

Cande, S. C., and Rabinowitz, P. D., 1979. Magnetic Anomalies of the Continental Margin of Brazil. Map Series, Am. Assoc. Pet. Geol., Tulsa, Oklahoma.

Carlson, R. L., and Christensen, N. I., 1977. Velocity anisotropy and physical properties of deepsea sediments from the western South Atlantic. In Supko, P. R., Perch-Nielsen, K., et al., Init. Repts. DSDP, 39: Washington (U.S. Govt. Printing Office), 555-560.

Gamboa, L. A., and Rabinowitz, P. D., 1981. Rio Grande Fracture Zone in the western South Atlantic and its tectonic implications. Earth Planet. Sci. Lett., 52:410-418.

Hinz, K., 1981. A hypothesis on terrestrial catastrophes: wedges of very thick oceanward dipping layers beneath passive continental margins. Geol. Jahr. Reihe E, 22:3-28.

Johnson, D. A., and Peters, C. S., 1979. Late Cenozoic sedimentation and erosion on the Rio Grande Rise. J. Geol., 87:371-392.

Kennett, J. P., and Shackleton, N. J., 1976. Oxygen isotopic evidence for the development of the psychrosphere $38 \mathrm{~m}$. yr. ago. Nature, 260:513-515.

Kumar, N., 1979. Origin of "paired aseismic rises": Ceara and Sierra Leone Rises in the equatorial, and the Rio Grande Rise and Walvis Ridge in the South Atlantic. Mar. Geol., 30:175-191.

Lonardi, A. G., and Ewing, M., 1971. Sediment transport and distribution in the Argentine Basin 4. Bathymetry of the continental margin, Argentine Basin and other related provinces-canyons and sources of sediments. Phys. Chem. Earth, 8:79-122.

Ludwig, W. J., Krashenninikov, V. A., et al., in press. Init. Repts. $D S D P, 71$ : Washington (U.S. Govt. Printing Office).

Macdonald, K. C., Miller, S. P., Huestis, S. P., and Spiess, F. N., 1980. Three-dimensional modeling of a magnetic reversal boundary from inversion of deep-tow measurements. J. Geophys. Res., $85: 3670-3680$.

McDowell, S., Kumar, N., Jacobi, R. D., Johnson, D. A., and Bunce, E. T., 1977. Regional setting of Site 357, north flank of Rio Grande Rise. In Supko, P. R., Perch-Nielsen, K., et al., Init. Repts. DSDP, 39: Washington (U.S. Govt. Printing Office), 955-969.

Maxwell, A. E., Von Herzen, R. P., et al., 1970. Init. Repts. DSDP, 3: Washington (U.S. Govt. Printing Office).

Mitchum, R. M., Vail, P. R., and Thompson, S., III, 1977. The depositional sequence as a basic unit for stratigraphic analysis. In Payton, C. E. (Ed.), Seismic Stratigraphy-Applications to Hydrocarbon Exploration: Tulsa, OK (Am. Assoc. Pet. Geol. Mem.), 26:53-62. 
Moody, R., Hayes, D. E., and Connary, S., 1979. Bathymetry of the Continental Margin of Brazil. Map Series, Am. Assoc. Pet. Geol., Tulsa, Oklahoma.

Mutter, J. C., Talwani, M., and Stoffa, P. L. 1982. Origin of seaward dipping reflectors in oceanic crust off te Norwegian margin by "subaerial sea-floor spreading." Geology, 10:353-357.

Neprochnov, Y. P., Merklin, L. R., and Supko, P. R., 1977. Underway geophysical measurements, Leg 39, Deep Sea Drilling Project. In Supko, P. R., Perch-Nielsen, K., et al., Init. Repts. DSDP, 39: Washington (U.S. Govt. Printing Office), 971-1044.

Parsons, B., and Sclater, J. G., 1977. An analysis of the variations of ocean floor bathymetry and heat flow with age. J. Geophys. Res., 82:803-827.
Roberts, D. G., Schnitker, D., and Shipboard Scientific Party, 1982. Leg 81 drill margin, Rockall Plateau. Geotimes, 27(9):21-23.

Supko, P. R., Perch-Nielsen, K., et al., 1977. Init. Repts. DSDP, 39: Washington (U.S. Govt. Printing Office).

Talwani, M., Udintsev, G., et al., 1976. Init. Repts. DSDP, 38: Washington (U.S. Govt. Printing Office).

Trehu, A. M., 1975. Depth versus (age) ${ }^{1 / 2}$ : a perspective on mid-ocean ridges. Earth Planet. Sci. Lett., 27:287-304.

Date of Initial Receipt: August 20, 1982 